\title{
François Villon retraduzido
}

\author{
Daniel Padilha Pacheco da Costa \\ "Eu sou Franco - quanto me pesa! \\ Nasci em Paris (perto a Pontesa) \\ E verá com a corda tesa \\ Meu colo quanto o meu cú pesa" \\ (François Villon, Quadra) ${ }^{1}$
}

\begin{abstract}
Resumo: Neste artigo, tratamos das diversas traduçôes para o português da poesia de François Villon, que é considerado o primeiro poeta moderno francês. Realizadas por importantes poetas da lingua, essas traducões procuram reproduzir as formas poéticas utilizadas por Villon. A tradução por Guilherme de Almeida da célebre Balata das damas dos tempos idos (1936) será estudada como exemplo paradigmático da concepscão de tradução pelos próprios tradutores do poeta francês em língua portuguesa.
\end{abstract}

Palavras-chave: François Villon, poesia, autor, tradução.

\section{Villon em língua portuguesa}

O corpo poético atribuído a François Villon foi composto na segunda metade do séc. XV, entre o final do reinado de Charles VII e o início do de Luís XI. A sua primeira edição por Pierre Levet no final do séc. XV foi intitulada

1 "Je suis Francois dont il me poise/ Né de Paris emprès Pontoise/ Et de la corde d'une poise/ Sçaura mon col que mon culpoise" (VILLON, F. Le Lais Villon et les poèmes variés, I. "Quatrain”. Edição Jean Rychner e Albert Henry, Genebra, Droz, 1977. Tradução nossa). 
O Grande Testamento de Villon e o Pequeno. Seu codicilo. O calão e suas baladas (1489). ${ }^{2}$ Essa edição é constituída por pouco mais de uma dúzia de formas fixas esparsas e por dois poemas longos em forma de testamentos. Essas composições são quase que inteiramente enunciadas em primeira pessoa pela personagem de François Villon. Plenamente reconhecível pelo público da época, esse nome próprio designava o célebre malfeitor "François des Loges, também chamado de Villon", segundo documentos judiciários descobertos no final do séc. XIX. ${ }^{3}$ A enunciação poética se investe da identidade desse indivíduo histórico, mas não é possível saber se ele foi o autor empírico daquele corpo poético. ${ }^{4}$

A personagem representa o tipo verossímil do jovem estudante vicioso e mundano, particularmente explorado no séc. XIII pelos poetas goliardos, por Rutebeuf etc. O nome próprio François Villon poderia ser traduzido por "Franco Vilão" em português, pois ele é um "nome falante" utilizado para figurar atributos da personagem, como a franqueza, a nacionalidade francesa, a vileza, etc. Embora não seja mais usual traduzirem-se nomes próprios, Vasco da Graça Moura traduz, seguindo antiga tradição portuguesa, o sobrenome Villon por "Vilão" na conclusão do Pequeno Testamento (XL, v. 313-314):

Fait au temps de ladite date Par le bien renommé Villon
Feito em tempo da dita data Pelo bem chamado Vilão ${ }^{5}$

Desde o início do Pequeno Testamento, o testador se apresenta em primeira pessoa com o nome próprio da personagem assumida na composição: “eu, Franco Vilão, estudante (...)". ${ }^{6}$ A retomada do seu nome na conclusão joga com a aparente validade jurídica do seu "testamento", pois o "bem chamado Villon" é um vilão sem bens. A tradução de Vasco da Graça Moura do sobrenome Villon pelo nome comum "Vilão" (Villain) produz um oxímoro na expressão "pelo

2 VILLON, F. Le grand testament Villon et le petit. Son codicile. Le jargon et ses balades. Publicado por Pierre Levet, Paris, 1489.

3 LONGNON, A. Étude biographique sur François Villon d'après les documents inédits conservés aux Archives nationales, Paris, Menu, 1877, p. 137.

4 Mesmo as suas mais antigas edições são póstumas: jamais publicado em vida pelo seu autor, esse corpo poético não recebeu nenhuma edição "autorizada”. Além disso, todos os seus manuscritos são apógrafos, nenhum deles é autógrafo (escrito do punho do próprio autor).

5 VILLON, F. Os Testamentos de François Villon algumas baladas mais; trad. Vasco da Graça Moura, Campo das Letras, Porto, 1997.

6 VILLON, F. Edição Jean Rychner e Albert Henry, Genebra, Droz, 1977. 
bem chamado Vilão". O trocadilho com o sobrenome da personagem do célebre malfeitor recupera a ironia da assinatura do testador autenticando a autoria do seu testamento.

Excetuada essa tradução de Vasco da Graça Moura da estrofe final do Pequeno Testamento, o nome próprio da personagem é mantido tal e qual pelos tradutores em todas as outras passagens da obra em que ele aparece. ${ }^{7}$ Como referência ao homem chamado "François Villon", o nome da personagem nas composições coincide com o do autor que aparece na capa de suas edições em língua portuguesa. ${ }^{8}$ Como todas as edições modernas desse corpo poético realizadas a partir do séc. XIX, as traduções em português identificam o célebre malfeitor da época com o autor empírico das composições.

Depois de ter permanecido praticamente três séculos relegado a segundo plano, Villon foi interpretado no séc. XIX a partir da concepção moderna de poesia, que é caracterizada pela indissociabilidade entre a experiência vivida pelo autor empírico e a sua expressão poética. A poesia atribuída a Villon exprimiria a vida de crimes, prisões, exílios, etc. de seu suposto autor. Assim, não tardou para que o poeta fosse considerado como um precursor dos "poetas malditos" na França. Fundador da disciplina da "História da Literatura", Gustave Lanson (18571934) elegeu François Villon o primeiro poeta moderno francês. .' Ocupando uma posição privilegiada na história da literatura francesa, Villon não passou despercebido à crítica no Brasil. A História da Literatura Ocidental (1959) de Otto Maria Carpaux (1900-1978) dedica um estudo monográfico a Villon que, como na História da Literatura Francesa de Gustave Lanson, é considerado o nascimento do lirismo moderno. ${ }^{10}$

Desse modo, a poesia de Villon foi destacada pela crítica moderna do contexto global da produção poética da França da segunda metade do séc. XV. ${ }^{11}$ Contemporâneo de Charles d'Orléans, Pierre Michault e Michault Taillevent, Villon

7 "Je Françoys Villon escollier" (Lais, I, v. 2); "Françoys Villon que travail a domptê" (Requeste a Monsieur de Bourbon, v. 5); "Je suis François dont il me poise" (Quatrain que feist Villon quant il fut jugé a mourir, v. 1) (VILLON, F. Edição Jean Rychner e Albert Henry, Genebra, Droz, 1977).

8 “Eu, François Villon, escolar" (RAMOS, P. E. S., Op. cit., p. 126); "Eu, François Villon, estudante” (LEITE, S. U., Op. cit. p. 61); “Eu, Francois Villon, escolar (...)” (MOURA, V. G. Op. cit., p. 49).

9 LANSON, G. Histoire de la littérature française, Paris, Hachette, 1923 (1894), p. 133.

10 Idem, p. 296.

11 DA COSTA, D. O Testamento do Vilão. Invenção e recepção da poesia de François Villon (2013). Na segunda parte desta tese, procuramos reconduzi-lo de volta a esse contexto, analisando-o com base nos preceitos e nos modelos poéticos que orientavam a invenção das letras na França do séc. XV. 
foi considerado mais próximo de Baudelaire, Rimbaud e Apollinaire. ${ }^{12}$ Como afirma o tradutor brasileiro Sebastião Uchoa Leite (1935-2003): "ele deixou de ser um poeta do século XV para tornar-se moderno". ${ }^{13}$ Villon tornou-se objeto de um sem número de edições e traduções desde o início do séc. XIX até hoje. Ele é dos raros poetas do período que despertaram maior interesse dos tradutores de língua portuguesa - todos eles importantes poetas brasileiros e portugueses. Traduziu-o Guilherme de Almeida, Augusto de Campos, Décio Pignatari, Péricles Eugênio da Silva Ramos, Afonso Félix de Souza, Sebastião Uchoa Leite, Jorge de Sena, Mário Faustino, Vasco da Graça Moura etc.

Guilherme de Almeida traduziu a Balata das damas dos tempos idos em Poetas de França, ${ }^{14}$ Mário Faustino a Balada em Velha Lingua Francesa,${ }^{15}$ Décio Pignatari a Balada da Gorda Margô,,${ }^{16}$ Augusto de Campos a Balada dos Enforcados, ${ }^{17}$ e Jorge de Sena a Balada das mulheres de Paris. Herculano de Carvalho também traduziu a Balada dos Enforcados, e a Balada das damas doutros tempos também foi traduzida por Claudio de Veiga. Além dessas traduções de baladas isoladas, os dois poemas longos em forma de testamento e as formas fixas esparsas atribuídas a Villon gozam de quatro traduções em português. Há duas traduções parciais e duas integrais da obra de François Villon em português - todas elas do final do séc. XX. Dessas quatro traduções da obra de Villon em língua portuguesa, três são brasileiras e uma é portuguesa.

As duas traduções parciais da obra de François Villon foram publicadas no final dos anos 80. A premiada tradução de Péricles Eugênio da Silva Ramos, os Poemas de François Villon (1986) são uma antologia de passagens do Pequeno e do Grande Testamento, e também incluem a tradução de algumas baladas esparsas. ${ }^{18} \mathrm{O}$ Grande Testamento foi integralmente traduzido por Afonso Félix de Souza, em edição intitulada $O$ Testamento (1987). ${ }^{19}$ Além disso, foram realizadas duas traduções praticamente integrais do corpo poético atribuído a François Villon em língua portuguesa. Vasco da Graça Moura é o tradutor da única tradução portuguesa, intitulada

12 KUHN, D. La Poétique de François Villon, Paris, Colin, 1967, p. 345.

13 LEITE, S. Jogos e enganos, Editora UFRJ, Rio de Janeiro, 1995, p. 42.

14 ALMEIDA, G. Poetas de França. Companhia Editora Nacional, São Paulo, 1965.

15 FAUSTINO, M. Poesia completa: poesia traduzida. Editora Max Limonad, São Paulo, 1985.

16 PIGNATARI, D. Traduções. Editora Hucitec, São Paulo, 1987.

17 POUND, E. Abc da literatura. Trad. Augusto de Campos e Paulo Paes, Cultrix, São Paulo, 1990.

18 VILLON, F. Poemas de François Villon. Trad. Péricles Eugênio da Silva Ramos, 1986.

19 VILLON, F. Testamento. Trad. Afonso Félix de Souza, 1987. 
Os Testamentos de Francois Villon e algumas baladas mais (1997)..$^{20}$ Ela inclui os dois poemas longos - intitulados "O Primeiro e O Segundo Testamento" -, e sete formas fixas esparsas atribuídas ao poeta (seis baladas e a quadra atribuída ao poeta).

Intitulada Francois Villon: Poesia (1987), a mais completa tradução do corpo poético atribuído a Villon em língua portuguesa foi realizada por Sebastião Uchoa Leite. ${ }^{21}$ Essa tradução inclui o Pequeno e o Grande Testamento, quatorze baladas esparsas, uma quadra, um rondó simples e uma epístola. Em relação ao corpo poético publicado pela edição Levet, a edição brasileira da Poesia de Villon só exclui as baladas em jargão: "Essa tradução exclui as baladas em jargão, por motivos óbvios: seria preciso haver um jargão equivalente em português ou então limitarse à tradução literal, o que não teria sentido". ${ }^{22}$ Além da ausência de um "jargão equivalente" em português, o sentido de diversos termos do jargão utilizado pela quadrilha dos Coquillards ainda permanece obscuro. Nenhuma das traduções em português do corpo poético atribuído a François Villon inclui as baladas em jargãa, que permanecem sendo as únicas composições atribuídas ao poeta desde a edição Levet sem nenhuma tradução na língua.

As quatro traduções da obra de Villon em português são edições bilíngues. O texto original publicado nas três edições brasileiras é o estabelecido pela edição de Auguste Longnon (1892) que, depois de ter sido revisado em diversas ocasiões por L. Foulet (1914, 1923 e 1932), tornou-se a mais importante edição moderna de Villon. A edição Longnon-Foulet utiliza como texto de base "a mais antiga edição de François Villon"23 por Pierre Levet. O texto da edição portuguesa é o da edição Dufournet, intitulada Poésies de Francois Villon (1984), ${ }^{24}$ que, por sua vez, baseia-se na edição Rychner-Henry. ${ }^{25}$ Rompendo com a tradição de utilizar a edição Levet como texto-base, a edição Rychner-Henry utiliza para isso o manuscrito Coislin, ${ }^{26}$ o mais completo manuscrito de Villon e o único que não é uma coletânea.

20 VILLON, F. Os Testamentos de François Villon e algumas baladas mais; trad. Vasco da Graça Moura, Campo das Letras, Porto, 1997.

21 VILLON, F. Poesia. Tradução de Sebastião Uchoa Leite. Edusp, 2000, São Paulo.

22 LEITE, S. U. Nota e Agradecimentos. In. VILLON, F. Poesia. Edusp, 2000, São Paulo, p. 9.

23 CHAMPION, P. La plus ancienne édition de François Villon. Paris, Editions des Quatre-Chemins, 1924.

24 VILLON, F.: Poésies. Éd. Jean Dufournet, Flammarion, Paris, 1992.

25 VILLON, F. Le Testament Villon. I: Texto, II: Comentários. Edição Jean Rychner e Albert Henry, Genebra, Droz, 1974.

VILON, F. Le Lais Villon et les poèmes variés, I: Texto, II: Comentários. Edição Jean Rychner e Albert Henry, Genebra, Droz, 1977.

26 Paris, Bibliothèque nationale de France. français, ms. 20041, f. 108r-112r (C). 
As quatro traduções da obra de Villon em língua portuguesa foram realizadas no último quarto de século. As três traduções brasileiras foram publicadas praticamente ao mesmo tempo (entre 1986/87), enquanto que a única tradução portuguesa foi publicada dez anos mais tarde (1997). Todas essas edições da obra de François Villon retomaram a crítica biográfica sobre o poeta. As traduções de sua obra são todas introduzidas pela biografia sobre o célebre malfeitor François des Loges, também chamado de Villon, como fazem as suas edições modernas desde a primeira metade do séc. XIX até hoje. A Vida de Francois Villon testemunha a modernidade da sua obra, como afirma Péricles Eugênio da Silva Ramos na introdução à sua antologia dos poemas de Villon (1986, p. 7):

François Villon, por muitos considerado o primeiro poeta moderno da França, embora haja vivido em fins da Idade Média e se vincule à tradição realística do século XIII, de Colin Muset e de Rutebeuf, tem uma biografia acidentada, na qual avultam crimes e prisões (...).

Considerado como precursor dos poetas malditos na França, Villon foi autor de poemas com uma carga pessoal própria à poesia moderna. A tradução de Sebastião Uchoa Leite a Poesia de François Villon inclui a única introdução ao poeta em língua portuguesa. Retomando concepção da persona de François Villon pela nova crítica produzida na França a partir do fim dos anos 60, ele insistiu na inextrincável mistura da vida na ficção poética. Nessa introdução, o herói romântico do submundo recebeu a tonalidade contemporânea do impostor armado de sua pena "contra os poderes". ${ }^{27}$

A imagem encontrada na biblioteca inteira escrita sobre François Villon não é tão variada quanto poderíamos esperar; pelo contrário, ela é incrivelmente convergente: "o primeiro poeta moderno", "o precursor dos poetas malditos", "o subversor da ideologia medieval", "o destruidor da retórica cortês", etc. Refletindo a crítica moderna sobre Villon na França, os tradutores de língua portuguesa são unânimes em considerá-lo como o "fundador" do lirismo moderno na História da literatura francesa.

\section{As traduções parciais e integrais}

Tanto o Pequeno quanto o Grande Testamento de Villon são poemas longos estruturados por sequências de estrofes com idêntica estrutura de ritmos e rimas.

27 VILLON, F. Poesia. Tradução, organização e notas: Sebastião Uchoa Leite, p. 43. 
Ambos utilizam a oitava: o Pequeno Testamento é inteiramente composto por oitavas e o Grande Testamento o é em sua maior parte. Nesse último, as sequências de oitavas são frequentemente intercaladas por baladas. O corpo poético de Villon utiliza principalmente a oitava no Pequeno e no Grande Testamento e a balada nesse último e nas formas fixas esparsas, mas ele também inclui alguns rondós duplos e uma quadra.

Todas as traduções em língua portuguesa dos dois testamentos e das formas fixas esparsas procuram reproduzir as formas poéticas utilizadas por Villon, mantendo as rimas e o verso metrificado dos poemas originais. Para todos os tradutores do poeta francês em português valem essas palavras de Sebastião Uchoa Leite: "na presente tradução houve um esforço de aproximação formal, pela métrica, pela rima, pelo ritmo". ${ }^{28}$ De acordo com o critério adotado por todos os tradutores de língua portuguesa, o aspecto essencial da poesia de François Villon a ser preservado na língua de chegada são as características da sua versificação, como o metro, o ritmo, a rima e a estrutura. Como afirma Vasco da Graça Moura: "foi o que fiz, procurando manter valores de metro, ritmo, rima e estrutura, relativamente próximos do original". ${ }^{29}$

No prefácio à sua tradução do Testamento, Afonso Félix de Souza justifica a sua escolha de procurar reproduzir a forma da oitava e da balada utilizada por Villon. Depois de tentar traduzir o Testamento em versão mais próxima da expressão poética moderna, sem métrica nem rimas, o tradutor percebeu que ele desfiguraria o espírito de Villon e decidiu manter em português as características da versificação do poeta. Como afirma Souza (1987, p. 10):

Pensei, por algum tempo, em apresentar o Testamento em versão mais próxima da expressão poética moderna, liberto da métrica e das rimas. À medida, porém, que o traduzia, ia percebendo que estava fugindo ao espírito de Villon. Sua linguagem, na qual prepondera o tom satírico, é por natureza desbocada, e a impressão que se tem é que a contenção em oitavas octossílabas e nas duras regras da balada gaulesa foi a maneira que Villon encontrou para conter-se até certo ponto, deixando apenas sugerida ou nas entrelinhas grande parte dos seus desabafos e invectivas. Assim, se traduzido em versos livres, como é aliás a versão em francês moderno que consultei, parece ficar faltando alguma coisa. Decidi-me então a seguir à risca a forma por ele adotada (...). ${ }^{30}$

28 LEITE, S. Op. cit., p. 10.

29 MOURA, V. Op. cit., p. 14

30 SOUZA, A. Op. cit., p. 10. 
Segundo o tradutor, a poesia de Villon se constitui pela tensão entre a rigorosa estrutura das formas fixas e a sua matéria predominantemente satírica: as oitavas e baladas de Villon modelam a matéria baixa das suas composições. A verve desbocada e o tom satírico de Villon são contrabalançados pelo rigor de suas formas poéticas. Ao insistir tanto na simetria Villon pretendia dar mais força às suas dissonâncias, como afirma Michel Butor em A Prosódia de Villon (1974). ${ }^{31}$

Enquanto todas as traduções em português utilizam rimas e versos metrificados, há em outras línguas traduções de Villon mais próximas da expressão poética moderna. A tradução inglesa de Galway Kinnell The Poems of François Villon (1982), por exemplo, é inteiramente composta em versos livres. Kinnell abre mão de rimas e de versos metrificados não por ignorar a sua organicidade em Villon, mas por pragmatismo. Utilizando o próprio Villon para justificar a sua escolha, ele considera a Ballade a s'amie como um dos poemas de maior virtuosismo técnico (essa balada utiliza o mais longo acróstico e todos os seus versos terminam com a letra "R"), mas de menor eficácia poética de Villon. ${ }^{32}$ Para reproduzir as formas fixas do poema original, o tradutor norte-americano considera ser necesssário sacrificar demasiado da qualidade poética de sua própria tradução. A escolha do verso livre em The Poems of François Villon evita não apenas recortar as palavras segundo a necessidade de completar uma rima, mas também utilizar adjetivos supérfluos para preencher um padrão métrico. Essa tradução privilegia a precisão verbal de Villon, optando por uma linguagem direta e pela fluência rítmica, segundo os princípios definidos pela poética "vorticista" de Ezra Pound..$^{33}$

Villon é um virtuose da rima. No Pequeno Testamento, por exemplo, as rimas são quase sempre ricas. Segundo Mário Laranjeira em Langage Poétique chę. Francois Villon (USP, 1972), a riqueza das rimas utilizadas no Pequeno Testamento atinge um ponto raramente alcançado pela poesia moderna. ${ }^{34}$ Indissociável do seu valor sonoro, o valor semântico de suas rimas é explorado pela busca de rimas nãocategoriais, de palavras exatas e com a sugestão de significados. Villon toma um cuidado muito especial com a rima, tanto do ponto de vista sonoro quanto semântico. Como afirma Pound, as rimas utilizadas por Villon apresentam enorme dificuldade técnica para o tradutor. ${ }^{35}$

31 BUTOR, M. “La prosodie de Villon”. In. Répertoire IV, 1974, p. 110.

32 KINNELL, G.: The Poems of Francois Villon, p. 21.

33 POUND, E. Apud. Poesia-Experiência, p. 148.

34 LARANJEIRA, M. Le langage poétique chez François Villon. Sous la direction du Prof. Dr. Vitor de Almeida Ramos au Département des Lettres Modernes de l’Université de São Paulo, 1972.

35 POUND, E. ABC da Literatura, trad. Augusto de Campos e Paulo Paes, Cultrix, São Paulo, 1990, p. 97. 
As rimas encontradas pelo poeta francês são a parte de seus poemas mais sacrificada pelas traduções em português. Os tradutores de Villon de língua portuguesa normalmente encontram rimas pobres, categoriais e sem sugestão de significados para não se afastarem demasiadamente do valor semântico de seus versos. Como afirma Péricles Eugênio da Silva Ramos: "as ordens das rimas foram seguidas, embora a maior parte das vezes em consoantes pobres, para resguardarem o mais possível o sentido do original". ${ }^{36}$ As traduções de Villon sempre respeitam o rigoroso esquema de rimas das oitavas de Villon, embora nem sempre elas mantenham o mesmo número de rimas da balada comum de Villon (três rimas diferentes nas baladas em octossílabos e quatro nas baladas em decassílabos). As traduções de Péricles E. da Silva Ramos e de Vasco da Graça Moura mantêm sempre o mesmo número de rimas da balada, repetindo as mesmas rimas ao longo das quatro estrofes. Os demais tradutores de língua portuguesa mudam com frequência as rimas entre as estrofes da balada. Sebastião Uchoa Leite chega a modificar o próprio esquema das rimas para traduzir algumas baladas de Villon. Nas oferendas de seis versos das baladas em decassílabos, por exemplo, ele substitui o esquema de duas rimas por um esquema de três, como, por exemplo, nas oferendas da Balada para rezar à nossa senhora e da Balada da Gorda Margot. ${ }^{37}$

Por ser o verso de medida menor mais utilizado pelos poetas de língua portuguesa desde os trovadores galego-portugueses, o redondilho maior foi frequentemente utilizado pelos poetas românticos para traduzir poemas franceses em octossílabos. Mas nenhum dos tradutores de Villon o adotou para reproduzir os seus octossílabos. Seguindo prática iniciada por parnasianos, ${ }^{38}$ os tradutores de Villon optaram em sua maioria pelo octossílabo em português para traduzir o mesmo em francês. Ritmo introduzido na língua por empréstimo, o octossílabo produz certo estranhamento em português, diferentemente da sua naturalidade em francês. Mas esse critério de correspondência do número de sílabas entre as línguas tem a vantagem de manter a estrofe quadrada das oitavas e baladas de Villon, que possui o mesmo número de sílabas no verso e de versos na estrofe.

As baladas compostas em decassílabos foram quase sempre traduzidas por decassílabos. Somente Péricles Eugênio rompe com o critério de correspondência, utilizando o decassílabo em suas traduções das oitavas e de algumas baladas em octossílabos: "nossa tradução procurou respeitar a forma do texto fran-

36 RAMOS, P. Op. cit., p. 11.

37 LEITE, S. Op. cit., p. 179 e 257, respectivamente.

38 FALEIROS, A. Elementos para a tradução do octossílabo em português, p. 76. 
cês, embora nem sempre na mesma medida: há baladas octossilábicas traduzidas em decassílabos, decassílabos postos em dodecassílabos". ${ }^{39} \mathrm{O}$ decassílabo confere maior margem para a tradução do octossílabo francês, mas é verso de andamento mais longo e quebra a agilidade do verso preferido de Villon. A adoção do decassílabo para o octossílabo francês levou-o a utilizar o dodecassílabo para traduzir algumas das baladas em decassílabos. As traduções de Péricles Eugênio das oitavas e de algumas baladas em octossílabos e em decassílabos rompem a simetria da estrofe quadrada.

\section{A Balada das damas dos tempos idos}

A Ballade de dames du temps jadis é sem dúvida uma das mais célebres composições de Villon; ela figura em todas as antologias de "Literatura Medieval", foi muito comentada pela crítica e até mesmo transformada em uma canção popular pelo compositor George Brassens. Primeira balada introduzida no Grande Testamento, a Balada das damas dos tempos idos é seguida por mais duas baladas consecutivas sobre o mesmo tema. A Balada das damas dos tempos idos, a Balada dos senhores dos tempos idos e a Balada em velha língua francesa, respectivamente, formam um tríptico sobre o mesmo tema. Última balada do tríptico, a Balada em velha língua francesa foi composta em "francês antigo" (ancien français), já desaparecido na época. Ao inventar formas imitando o francês antigo, Villon dramatiza na própria língua a transitoriedade do mundo temporal, como se a própria voz poética estivesse em vias de desaparecer enquanto lembra daquelas mulheres.

$\mathrm{Na}$ Balada das damas dos tempos idos, o lugar comum “onde estão?" (ubi sunt?) é aplicado a célebres mulheres tragadas pela morte. Segundo o lugar comum da traição das mulheres, Villon seleciona mulheres ilustres do passado que foram responsáveis pela ruína dos homens. Assim, ele lembra que a morte adveio ao homem depois da sua expulsão do paraíso por causa da mulher primeva - Eva. $\mathrm{Na}$ balada, prevalece a ordem temporal na enumeração das mulheres, avançando em um crescendo desde as personagens de um passado distante na antiguidade até o presente próximo. Aterrorizado pela aproximação de sua própria morte, o poeta interpela a Nossa Senhora no fim da composição: "Onde elas estão, virgem soberana?" Ao contrário da perdição do Homem por causa de Eva, a mãe de Cristo representa a promessa da salvação.

39 RAMOS, P. Op. cit., p. 10/11.

40 “Ou sont ilz, ou, Vierge souveraine?” (VILLON, F. Le Testament Villon. Edição Jean Rychner e Albert Henry, Genebra, Droz, 1974). 
A invocação convencional do príncipe na oferenda é recoberta de ironia, pois é de pouco monta ser príncipe nesta vida, se comparado ao "lugar" aonde se vai depois da morte. Segundo o lugar comum da igualdade da morte, Villon lembra que a morte não poupa a ninguém, dirigindo a pergunta do refrão ao príncipe: "Mas onde estão as neves de antanho?" Retirada da Bíblia, ${ }^{41}$ a imagem da neve no refrão refere a morte ao inelutável ciclo das estações da natureza.

Pertencente à primeira parte do Grande Testamento, essa balada desenvolve, portanto, a reflexão da personagem do célebre malfeitor sobre a iminência da morte. Ela permite compreender a enunciação poética do Grande Testamento como a dramatização de sua angústia diante da dúvida sobre o lugar aonde a sua alma irá depois da morte. A pergunta retórica é uma figura utilizada quando perguntamos o que nós queremos afirmar. ${ }^{42}$ A pergunta pelo lugar aonde foram célebres personagens históricas serve para o ensinamento da vanidade do mundo temporal, segundo o lugar comum do "desprezo pelo mundo". Considerados da perspectiva da salvação da alma, os bens terrenos como riqueza, glória, beleza, honra, poder etc. não possuem valor algum.

Publicada na coletânea de traduções Poetas de França (1936, p. 27), a tradução de Guilherme de Almeida dessa balada de Villon foi a primeira composição do poeta francês vertida em língua portuguesa:

\section{Ballade des dames du temps jadis ${ }^{43}$}

Dictes moy ou n'en quel pays

Est Flora la belle Romaine Archipiadés ne Thaÿs

Qui fut sa cousine germaine Echo parlant quant bruyt on maine

Dessus riviere ou sur estan, Qui beaulté ot trop plus qu'umaine Mais ou sont les neiges d'anten?

Ou est la tres sage Esloÿs

Pour qui chastré fut et puis moyne

\section{Balata das damas dos tempos idos ${ }^{44}$}

Digades-m'u, em q paiz He Flora, a fremosa Romana? Archipiades, ob Thais, foy sua prima germana? Echo, a falar se rruydo emana D'estagno ob rribeiras q vam, Q belleza ouve mays q humana?... Mas u sam as neves d'entam!

U a muy acordada Heloiz Por qm, crastado, poz sotana

41 Jó, 6/15-17 (BÍBLIA SAgRADA. Tradução de Antônio Pereira de Figueiredo, São Paulo, Ed. Rideel, 1997.

42 LEGRAND, Jacques., L'Arcbiloge Sophie, Paris, Champion, 1991, p. 137.

43 VILLON, F. Le Testament Villon. Edição Jean Rychner e Albert Henry, Genebra, Droz, 1974.

44 ALMEIDA, G. Op. cit., p. 27. 
Pierre Esbaillart a Saint Denys?

Pour son amour eust ceste essoyne.

Semblablement, ou est la royne

Qui commanda que Buriden

Fust gecté en ung sac en Saine

Mais ou sont les neiges d'anten?

La Royne Blanche comme liz,

Qui chantoit a voix de seraine,

Berthe au plat pié, Bietrix, Aliz,

Haranburgis qui tint le Maine,

Et Jehanne la bonne Lorraine,

Qu'Engloys brulerent a Rouen:

Ou sont ilz, ou, Vierge souveraine?

Mais ou sont les neiges d'anten?

Prince, n'enquerrez de sepmaine

Ou elles sont ne de cest an,

Qu'a ce reffraing le vous remaine:

Mais ou sont les neiges d'anten?
Pero Abelardo, en Sam Denis?

Por seo amor ouve tal damno.

Ygualmente, $u$ he a tirana

Q a Buridan fez, nhum curram,

Geytar oo Sena, sorte insana?

Mas u sam as neves d'entam!

E a rreynha Branca qual Liz,

Q cantava de voz louçana,

Bertrada a grade, Alliz, Beatriz,

Haremburga, do Maine ufana, E a boa Lorena Jhoanna

Q Engreses queimarom en Ruam: E u Sam, Virge soberana?...

Mas u sam as neves d'entam!

Principe, nam percaes somana

E ano, a esguardar u elas Sam,

Ca este refram vos nam engana:

Mas u sam as neves d'entam!

A forma de balada utilizada por Villon nessa composição é chamada de "balada comum" pelas Artes de Segunda Retórica da época. ${ }^{45} \mathrm{~A}$ balada comum possui três estrofes, concluindo-se por uma oferenda com a metade do número de versos da estrofe; cada uma dessas quatro estrofes se conclui pelo mesmo refrão, que condensa a matéria da balada; as mesmas rimas são repetidas ao longo das três estrofes e da oferenda, que repete as rimas da segunda metade da estrofe. A tradução de Guilherme de Almeida reproduz com o mais extremo rigor a forma da balada de Villon. O tradutor mantém apenas três rimas repetidas ao longo das quatro estrofes. ${ }^{46} \mathrm{O}$ ritmo fluente do octossílabo francês intercalando versos masculinos e femininos é reconstruído em português por meio da alternância entre rimas de palavras oxítonas e paroxítonas.

Realizada duas décadas depois, a tradução modernizante de Décio Pignatari da Balada da Gorda Margố (1955) utiliza gírias paulistanas e expressões vulgares

45 MOLINET, J. L'Art de Rhétorique. In. LANGLOIS, E. Recueil d'Arts de Seconde Rhétorique. Paris, Imprimerie nationale, 1902, p. 235.

46 Há apenas uma falha na rima em - ano (damno) da segunda estrofe, que deveria terminar em -ana, como as demais. 
para recriar as obscenidades da Sotte balade de Villon em português. ${ }^{47}$ A "transcriação" de Pignatari se inspira na tradução por Ezra Pound das Traquinias de Sófocles e de algumas odes selecionadas por Confúcio, onde ele utiliza as gírias e a dicção coloquial do slang norte-americano. ${ }^{48}$ Consciente de que a tradução necessariamente moderniza o poema original, o poeta concretista assume a "persona" de Villon para, explorando os recursos da língua falada no seu próprio contexto social, reproduzir os efeitos poéticos do texto original.

Ao contrário da tradução modernizante de Décio Pignatari, Guilherme de Almeida optou por uma tradução arcaizante em sua Balata das damas dos tempos idos. A exploração sistemática de arcaísmos pela sua tradução produz um forte efeito de artificialidade, mas esse efeito é deliberado e visa a produzir distanciamento no leitor moderno. A tradução de Guilherme de Almeida produz efeito análogo àquele produzido pelo Inferno de Dante traduzido por Littré, que imitou o francês antigo em sua tradução do primeiro livro da Divina Comédia. A utilização de arcaísmos é própria ao estilo grave, que é utilizado por gêneros elevados, como o poema de Dante, por exemplo, mas o excesso de arcaísmos recai no vício da obscuridade. Da mesma forma que a exploração sistemática de formas do francês antigo por Littré pretende tornar venerável a sua tradução do poema medieval considerado como o fundador da "Literatura Italiana", a proliferação de formas do português antigo pretende fazer o mesmo com a tradução da mais célebre balada do "primeiro poeta moderno" da História da literatura francesa.

Mas nem Dante nem tampouco Villon eram "medievais" em seu tempo. Diferentemente da tradução de Guilherme de Almeida, a Ballade des dames du temps jadis de Villon não produzia o mesmo efeito de distanciamento sobre os ouvintes da época. Por outro lado, a Balada em velha lingua francesa do Grande Testamento produzia um efeito nos ouvintes da época análogo àquele produzido pela tradução de Guilherme de Almeida no seu público contemporâneo. Da mesma forma que o léxico e a grafia da Ballade en vieil langage françys imita o francês antigo, o léxico e a grafia da Balata das damas dos tempos idos traduzida por Guilherme de Almeida imita o português antigo. Portanto, o poeta modernista brasileiro assimilou à sua tradução a exploração de arcaísmos da Balada em velha língua francesa ${ }^{49} \mathrm{~A}$ Balata das damas dos tempos idos funde a primeira e a última balada do tríptico de baladas do Grande Testamento sobre o lugar comum "onde estão?"

47 PIGNATARI, Décio. Traducões. São Paulo, Editora Hucitec, 1987.

48 SOPHOCLES, Women of Trachis.Version by Ezra Pound. tradução de Ezra Pound, London, Neville Spearman, 1956; The Classic Anthology defined by Confucius, tradução de Ezra Pound, London, Faber and Faber, 1955.

49 LEITE, Sebastião Uchoa, Jogos e Enganos, Rio de Janeiro, Editora UFRJ, 1995, p. 30. 
Guilherme de Almeida recusa à sua coletânea de traduções da poesia francesa o título de "antologia", mas reivindica os poemas traduzidos como fundadores de sua própria poética: enquanto poemas por si mesmos, as traduções de Poetas de França se apresentam como emulações da poesia moderna francesa. ${ }^{50} \mathrm{O}$ poeta modernista brasileiro escolheu a sua tradução da Balada das damas dos tempos idos para abrir a sua coletânea de traduções de poetas de França, refletindo a concepção historiográfica de Villon como "o primeiro poeta moderno francês". A utilização de arcaísmos faz a tradução de Guilherme de Almeida parecer tão antiga quanto o poema "original", como se ela não fosse uma "tradução", mas uma cantiga de um trovador galego-português.

Exploração poética das potencialidades da língua de chegada, a Balata das damas dos tempos idos de Guilherme de Almeida pode ser considerada como um exemplo paradigmático da concepção de tradução dos próprios tradutores do poeta francês em língua portuguesa. Desde a Balata das damas dos tempos idos de Guilherme de Almeida até Os Testamentos de François Villon e outras baladas mais de Vasco da Graça Moura, as traduções em português procuram reproduzir o extremo rigor formal de suas formas poéticas. Realizadas por importantes poetas da língua, as traduções de Villon se apresentam como poemas por si mesmos em português. Assim, as diversas traduções das Baladas esparsas, do Pequeno e do Grande Testamento de Mestre François Villon emulam "o primeiro poeta moderno francês", cuja poesia, mais de quinhentos anos depois, ainda ecoa "d'estagno ob rribeiras q vam"...

\section{Referências}

ALMEIDA, G. Poetas de França, Companhia Editora Nacional, São Paulo, 1965.

BÍBLIA SAGRADA. Tradução de Antônio Pereira de Figueiredo, São Paulo, Ed. Rideel, 1997.

CARPAUX, O. História da Literatura Ocidental. Rio de Janeiro, Alhambra, 1985.

CHAMPION, P. La plus ancienne édition de François Villon. Paris, Editions des QuatreChemins, 1924.

DA COSTA, D. O Testamento do Vilão - Invenção e Recepção da Poesia de François Villon. Tese apresentada ao Departamento de Letras Modernas da Faculdade de Filosofia, Letras e Ciências Humanas da Universidade de São Paulo, 2013.

FALEIROS, A. Elementos para a tradução do octossílabo em português. Cadernos de Literatura em Tradução, VII, Humanitas, São Paulo, 2006.

50 ALMEIDA, G. Op. cit, p. 21. 
FAUSTINO, M. Poesia completa: poesia traduzৃida. Editora Max Limonad, São Paulo, 1985. Poesia-experiência. Editora Perspectiva, São Paulo, 1977.

GILSON, É. De la bible a François Villon. Librarie Philosophique J. Vrin, Paris, 1986.

KUHN, D. La Poétique de François Villon, Paris, Colin, 1967.

LANGLOIS, E. Recueil d'Arts de Seconde Rhétorique. Paris, Imprimerie nationale, 1902.

LANSON, G. Histoire de la littérature française. Paris, Hachette, 1923 (1984), t. I.

LARANJEIRA, M. Poética da Tradução: do sentido à significância, Editora da USP, São Paulo, 1993.

. Le langage poétique chez François Villon. Sous la direction du Prof. Dr. Vitor de Almeida Ramos au Département des Lettres Modernes de L’Université de São Paulo, 1972.

LEGRAND, Jacques. L'Archiloge Sophie, Paris, Champion, 1991.

LONGNON, A. Étude biographique sur Francois Villon d'après les documents inédits conservés aux Archives nationales, Paris, Menu, 1877.

LEITE, S.: Jogos e Enganos. Editora UFRJ, Rio de Janeiro, 1995.

MESCHONNIC, H.: Poétique du traduire. Verdier, France, 1999.

PIGNATARI, D. Traduções. Editora Hucitec, São Paulo, 1987.

POUND, E. $A B C$ da Literatura; trad. Augusto de Campos e Paulo Paes, Cultrix, São Paulo, 1990.

The Classic Anthology defined by Confucius, tradução de Ezra Pound, London, Faber and Faber, 1955.

SOPHOCLES, Women of Trachis. Version by Ezra Pound. Tradução de Ezra Pound, London, Neville Spearman, 1956.

VILLON, F. Poésies. Éd. Jean Dufournet, Flammarion, Paris, 1992.

. Le Testament Villon. I: Texto, II: Comentários. Edição Jean Rychner e Albert Henry, Genebra, Droz, 1974.

Le Lais Villon et les poèmes variés, I: Texto, II: Comentários. Edição Jean Rychner e Albert Henry, Genebra, Droz, 1977.

Le grand testament Villon et le petit, son codicile, le jargon et ses balades. Publicado por Pierre Levet, Paris, 1489.

Poemas de François Villon; trad. Péricles Eugênio da Silva Ramos, Art Editora, São Paulo, 1986.

Testamento; trad. Afonso Félix de Souza, Editora Itatiaia, Belo Horizonte, 1987.

François Villon: Poesia. Trad. Sebastião Uchoa Leite, Edusp, São Paulo, 2000.

The Poems of Francois Villon; trad. Galway Kinnell, University Press of New England, Hanover and London, 1977.

Os Testamentos de François Villon; trad. Vasco da Graça Moura, Campo das Letras,

Porto, 1997. 